\title{
人工筋肉を目指した形状記憶合金アクチュエータ* （運動単位の特性）
}

\author{
石川敏 也*1, 中田毅*1
}

\author{
Shape Memory Alloy Actuator for Artificial Muscle \\ (Characteristics of Motor Unit)
}

\author{
Toshiya ISHIKAWA and Takeshi NAKADA*2 \\ ${ }^{* 2}$ School of Information Environment, Tokyo Denki University, \\ 2-1200 Muzai Gakuendai, Inzai-shi, Chiba, 270-1382 Japan
}

\begin{abstract}
In this study we aim to realize an actuator that is comparable with a natural muscle from a viewpoint of flexibility, the output force and the responses. In the 1st report we constructed the Shape Memory Alloy (SMA) actuator protected by "a rolled film tube" with the high heat resistance and the high flexibility, and it is named "the unit cell". In this report we constructed an actuator named "a motor unit" with the larger output force by bunching up 7 unit cells, and the characteristics of the motor unit are investigated by the experiments in which the motor unit is driven in Pulse Frequency Modulation (PFM). The result of the experiments shows that the static characteristics of the output force and the displacement to the input pulse frequency in the motor unit near proportion relations in comparison with the unit cell still more and the output force increases almost 7 times as large as the unit cell. It is found out that the time constant of the motor unit becomes larger compared to that of the unit cell, and the power conversion efficiency falls when pulse width is extended to improve the time constant.
\end{abstract}

Key Words: Shape Memory Alloy, Actuator, Artificial Muscle, Robot, Bio-Motion, Rolled Film Tube, Unit Cell, Motor Unit, Pulse Frequency Modulation

\section{1. 緒言}

近年, 必要性が高まりつつある人間親和性の高い口 ボットには, 人間に近い形態と柔軟性が要求されると 考えられる。そのようなロボットに使用する人工筋肉 としてのアクチュエータに, 形状記憶合金(Shape Memory Alloy. 以降 SMA と呼ぶ)が, 大きな発生 力と発生変位をもつうえに柔軟性にも優れることから 多くの研究機関で研究されている.

応答性を高め大きな発生力を得るために, 熱容量の 小さな細いSMA ワイヤを高密度に複数立列配置して 用いる場合, 電気的短絡や絡み合い等が生じない程度 の狭い間隔に配置すると, 柔軟に折り曲げることがで きなくなるうえ各ワイヤの周囲空間に熱が溜まるので 強制的に冷却する必要性が生じる.

そこで, SMA ワイヤを柔軟性の高いチューブに挿 入して束ね合わせ，チューブに冷却流体を流して冷却 する方式が考えられる，しかし，このチューブには高 い柔軟性と SMA の発する高熱に対する耐熱性が必要

* 原稿受付 2007 年 4 月 16 日.

*1 正員, 東京電機大学情報謤境学部(画270-1382 印西市武西 学園台 2-1200).

E-mail : nakada@ sie.dendai.ac.jp
であり,この 2 条件を同時に満たせるチューブは, 従 来存在していなかった。

以上の問題点を解決する手段として耐熱性と柔軟性 の両方に優れた SMA 専用機械要素「巻フィルムチュ ーブ(Rolled film tube)」を提案し，これに細いSMA ワイヤを素線とするコイルばねを挿入して人工筋肉の 最小単位「単セル(Unit cell)」を製作し, 生体の神経 インパルスで義手を駆動する場合を想定して生体神経 インパルスと同じ幅と同じ周波数帯域の電圧パルス列 によるパルス周波数変調(Pulse Frequency Modulation. 以降, PFM)にて駆動実験を行った。その結果, パルス周波数にほほ比例する発生力と発生変位を得 た

本報では，高出力化を図るため単セルを複数束ね合 わせ, 生体紡鍾筋状の「運動単位(Motor unit)」を組 立て, PFM 駆動実験を行った。その結果単セル同様, パルス周波数にほほ比例する発生力と発生変位が得ら れることを検証した，しかし同時に応答時間(時定数) が単セルより $1.0 \mathrm{~s}$ 以上も長くなる問題が明らかにな った ${ }^{(2)}$. そこで, この時定数の延長化問題に対処する ため, PFM のパルス幅を $1.0 \mathrm{~ms}$ 以上にすると, 時定 数を単セルレベルまで短縮できることがわかった。

さらにこの結果を基に, PFM のパルス幅を制御す 
ることでパルス周波数の時定数への影響を抑制し，ま た運動単位への投入電力とパワー変換効率を求め, パ ワ一変換効率は現状数\%であることがわかった ${ }^{(3)}$.

\section{2. 運動単位の構成}

解剖学では 1 本の運動神経に支配される筋細胞の束 を運動単位(Motor unit) と呼び(4)(5), 「単セル(Unit cell)」は，この筋細胞に該当する。そこで本研究で は,この単セルの束を「運動単位(Motor unit)」と呼 ぶ.

単セルは耐熱性と柔軟性の両方に優れる「巻フィル ムチューブ(Rolled film tube)」の中に, 細いSMA ワイヤを素線とするコイルばねを図 1 ( a )のように挿 入し両端にアラミド系と電線を取付けた構成をしてお

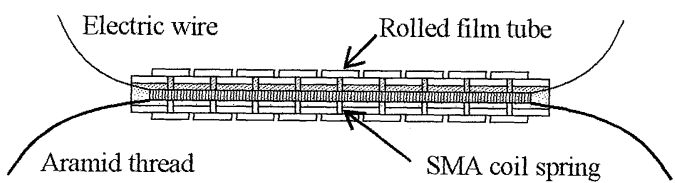

(a) Inside of unit cell

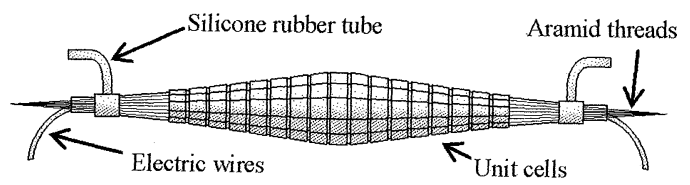

(b) View of motor unit

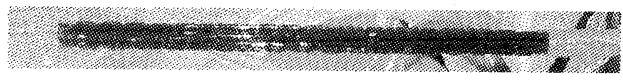

(c) Photograph of motor unit

Fig. 1 Motor unit

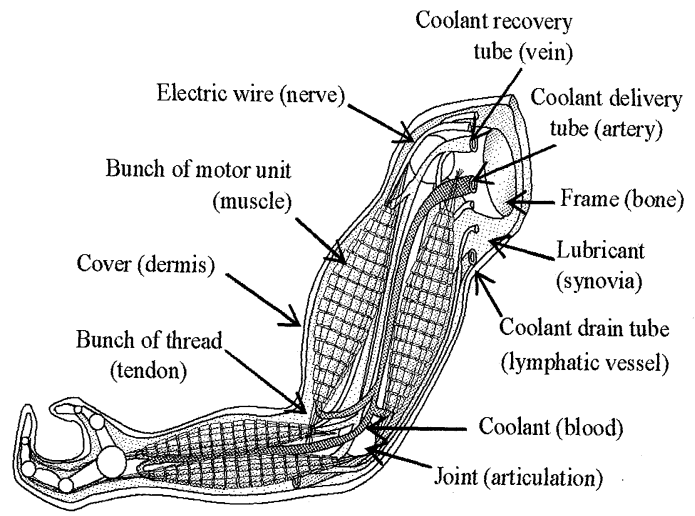

Fig. 2 View of artificial muscle arm
り，中に冷却液を通すことで図 $1(\mathrm{~b})$ のように束ね合 わせた場合でもおのおのの SMA コイルばねを均一に 冷却できる。図 1 ( c ) に運動単位の写真を示す。実用 上は，この運動単位を複数用いることで図 2 のような 人工の腕などへの応用が考えられる(1).

\section{3. 実験装置と方法 ${ }^{(3)}$}

図 3 に本研究の実験装置の ( a ) 正面図と (b) 側面図 を示す. 表 1 に本研究で使用した運動単位を構成する 単セルの仕様を示し, その運動単位の構成を図 4 に示 す。体積を小さくするため断面積が最小となる円に近 づくように，単セルを 7 本束ね合わせた，その総重量 は $1.05 \mathrm{~g}$ である。冷却液は, 電気絶縁性の高い不活 性液体で, 供給側と回収側のチューブポンプで運動単 位の下から上に向けて流されており，その液温はヒ一 夕と熱電対とかくはん機で構成された温調システムで $36^{\circ} \mathrm{C}$ に保たれている. 表 2 に本研究の冷却用不活性液 体の仕様を示す，運動単位上端部の系はプーリ 1 に向 かって時計回りに 1 回まわして掛けてあり, 発生変位

Table 1 Specifications of unit cell

\begin{tabular}{|c|c|c|}
\hline \multirow{3}{*}{ Rolled film tube } & Outer diameter $(\mathrm{mm})$ & $\phi 1.5$ \\
\cline { 2 - 3 } & Length $(\mathrm{mm})$ & 100 \\
\hline \multirow{3}{*}{ SMA coil spring } & Coil outer diameter $(\mathrm{mm})$ & $\phi 0.6$ \\
\cline { 2 - 3 } & SMA wire diameter $(\mathrm{mm})$ & $\phi 0.2$ \\
\cline { 2 - 3 } & Length $(\mathrm{mm})$ & 80 \\
\cline { 2 - 3 } & Phase transformation temperature $\left({ }^{\circ} \mathrm{C}\right)$ & 60 \\
\hline \multirow{2}{*}{ Weight $(\mathrm{g})$} & 0.15 \\
\hline
\end{tabular}

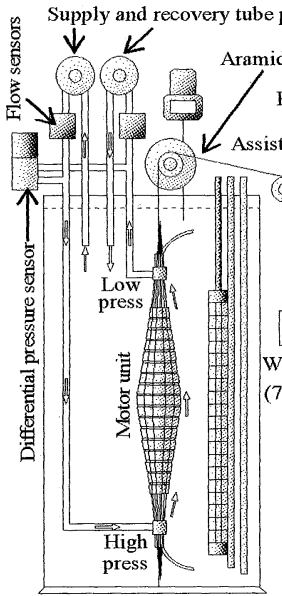

(a) Front view

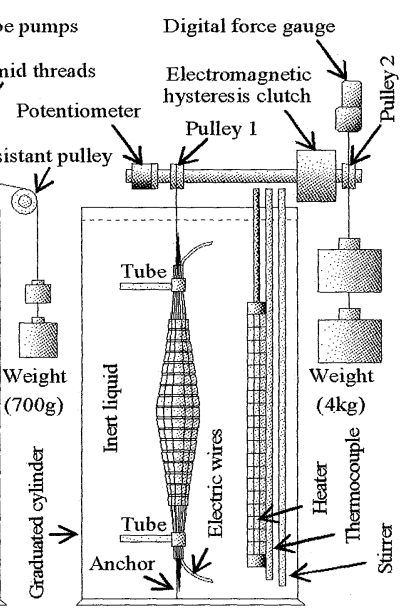

(b) Side view
Fig. 3 Experimental apparatus 
Table 2 Specifications of inert liquid

\begin{tabular}{|c|c|}
\hline \multicolumn{2}{|c|}{ Hydrofluoropolyether (HFPE) } \\
\hline Boiling point $\left({ }^{\circ} \mathrm{C}\right)$ & 178 \\
\hline Density $\left(\mathrm{kg} / \mathrm{m}^{3}\right)$ & 1720 \\
\hline Specific heat $(\mathrm{J} /(\mathrm{kg} \cdot \mathrm{K}))$ & 1092 \\
\hline Thermal conductivity $(\mathrm{W} / \mathrm{m} \cdot \mathrm{K})$ & 0.087 \\
\hline
\end{tabular}

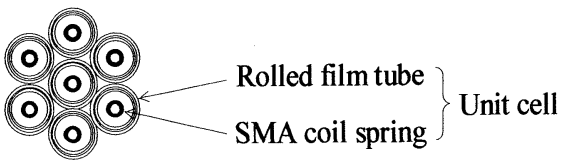

Fig. 4 Cross section of motor unit

は，その系の先端に $7 \mathrm{~N}$ の分銅 $(700 \mathrm{~g})$ を掛けて, ポテ ンショメータの回転角にて検出する.プーリ 1 の同軸 上には同径 $(\phi 20 \mathrm{~mm})$ のプーリ 2 が設けられており, 二つのプーリはヒステリシスクラッチにて分離・接続 される.プーリ 2 にも糸が向かって時計回りに 1 回ま わしてあり，その上端部はディジタルフォースゲージ に掛けられ，下端部には $40 \mathrm{~N}$ の分銅 $(4 \mathrm{~kg})$ がつるさ れ $40 \mathrm{~N} \cdot \mathrm{cm}$ のブレーキトルクが掛かっている. 発生 力の検出は, まずプーリ 1 とプーリ 2 を分離し, 運動 単位の糸に $7 \mathrm{~N}$ の分銅 $(700 \mathrm{~g})$ を掛けて引き伸ばし予 ひずみを与える。次に, プーリ 1 とプーリ 2 を接続し て SMA を通電加熱すると, 運動単位は収縮しようと するがプーリ 2 にブレーキが掛かっているため静止状 態を保ち, ヒステリシスクラッチを介してプーリ 2 に 掛かった $40 \mathrm{~N} ・ \mathrm{~cm}$ のトルクに反トルクが掛かりディ ジタルフォースゲージの表示が $40 \mathrm{~N}$ 以下になる。こ の軽くなった分が運動単位の発生力である.

\section{4. 実験結果と考察}

$4 \cdot 1$ 発生力・発生変位の静特性 運動単位は単 セルと同様，一定冷却液流量のもとで一定周波数のパ ルス電圧を入力すると, それに応じた一定の力と変位 を静的に発生することが, 予備実験で確認されてい る(2). そこで, 5 種類の冷却液流量において, 運動単 位に生体神経インパルスと同じ幅 $(0.5 \mathrm{~ms})$ で同じ周 波数帯域 $(10 \sim 70 \mathrm{~Hz})$ である一定周波数の電圧パルス 列を入力し，そのとき発生する力と変位をパルス周波 数ごとに測定した．電圧パルスの高さは使用スイッチ 素子の定格電圧 $100 \mathrm{~V}$ に固定した. 冷却液流量の大 きさはポンプの最低流量である $28 \mathrm{ml} / \mathrm{min}$ から, 冷却 液の流動力によって運動単位の変位が影響を受けない 流量である $105 \mathrm{ml} / \mathrm{min}$ までの範囲内の 5 種類で設定

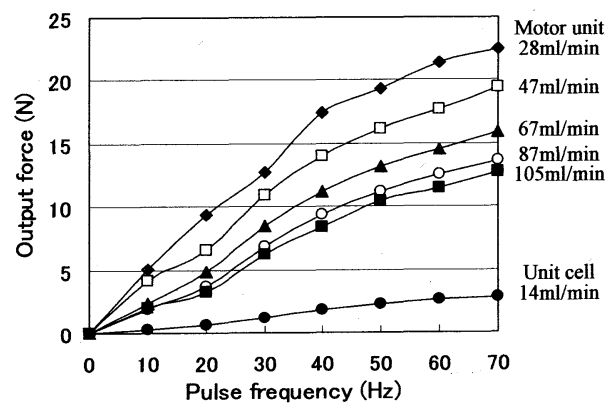

(a) Output force

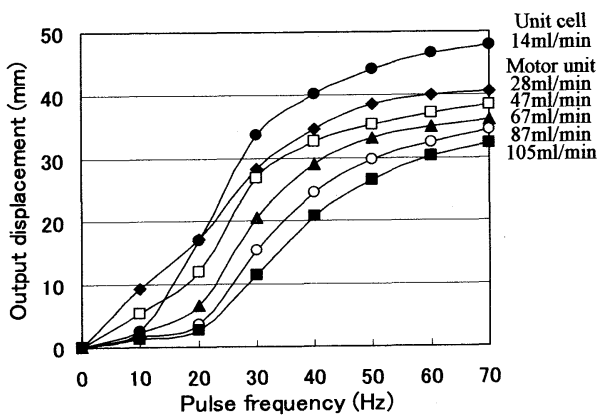

(b) Output displacement

Fig. 5 Pulse frequency characteristics of motor unit and unit cell

した．冷却液流量をパラメータにしてパルス周波数に 対する発生力と発生変位の関係を求め, その結果を図 5 ( a ), (b ) に示す. 比較のため, 単セル 1 本の場合 (冷却液流量: $14 \mathrm{ml} / \mathrm{min}$, パルス周波数: $70 \mathrm{~Hz}$ )で の結果 (最高発生力 : $2.8 \mathrm{~N}$, 最高発生変位: $48 \mathrm{~mm}$ : 元の長さの 48\%) を図 5(a), (b) 中に挿入した.

図 5 によれば単セル 1 本に対し，7本束ね合わせた 運動単位では, 冷却液流量 $: 28 \mathrm{ml} / \mathrm{min}$, パルス周波 数: $70 \mathrm{~Hz}$ で, 最高発生力: $22.5 \mathrm{~N}$, 最高発生変位： $40.6 \mathrm{~mm}$ (元の長さの $40.6 \%$ ) となった.この結果, 単セルを 7 本束ね合わせて運動単位にした場合, 発生 力は単セルの本数とほほ同数倍になっており, 束ね合 わせる単セルの本数に応じて運動単位の発生力が大き くなることが明らかになった。一方, 発生変位は単セ ルの約 $85 \%$ であり, 発生変位が若干小さいのは, 単セ ルの束ね合わせによる摩擦の影響と考えられる。

$4 \cdot 2$ パルス周波数とステップ応答 運動単位の 冷却液流量は, 単セルの約 7 倍の $105 \mathrm{ml} / \mathrm{min}$ に固定 してステップ応答の実験を行った．その結果を図 6 （a），（b）に示す。比較のため，単セル 1 本の場合(冷 却液流量: $14 \mathrm{ml} / \mathrm{min}$, パルス幅: $0.5 \mathrm{~ms}$, パルス周 波数：70 Hz)での発生力と発生変位のステップ応答 
を図 6(a)，(b)中に示す.図6(a)，(b) 屿, $0 \mathrm{~s}$ 時 に幅 $0.5 \mathrm{~ms}$, 高さ $100 \mathrm{~V}$ の各種周波数の電圧パルス 列を加えたときの運動単位と単セルの発生力と発生変 位の時間的変化を表している.

この結果から, 運動単位の場合でも単セル同様, い ずれのパルス周波数においても発生力と発生変位のス テップ応答は, 近似的に一次遅れの特性を示すことが わかった。

この図 6 から時定数 $T$ について, 単セル単独の発 生力では $0.6 \mathrm{~s}$, 発生変位では $0.4 \mathrm{~s}$ なのに対し, 時定 数が最も小さくなる $70 \mathrm{~Hz}$ の場合でも単セルを 7 本 束ね合わせた運動単位の発生力では $1.5 \mathrm{~s}$, 発生変位 では $1.8 \mathrm{~s} て ゙ あ り ，$ 単セルと比べて発生力の時定数は 2.5 倍に, 発生変位の時定数は 4.5 倍になることがわ かった。

$4 \cdot 3$ パルス幅とステップ応答特性 $\quad 4 \cdot 2$ 節で述 べた時定数の延長化の原因は, 図 4 のように単セルを 束ね合わせると, 単セル間のすきまの体積が運動単位 の体積に加わり熱容量が増え，その加温に熱が消費さ れて SMA の温度上昇時間が延長化したものと考えら れる.

そこで不足分の熱量を運動単位に投入する電力で補

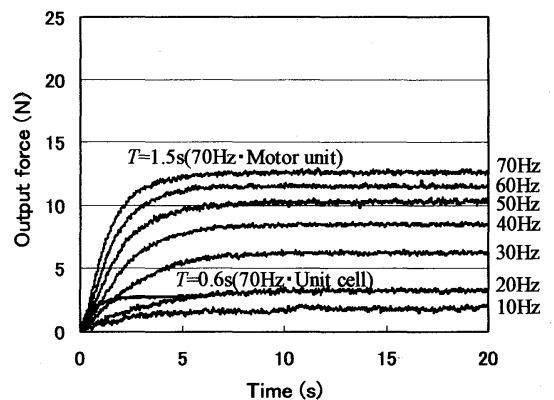

(a) Output force

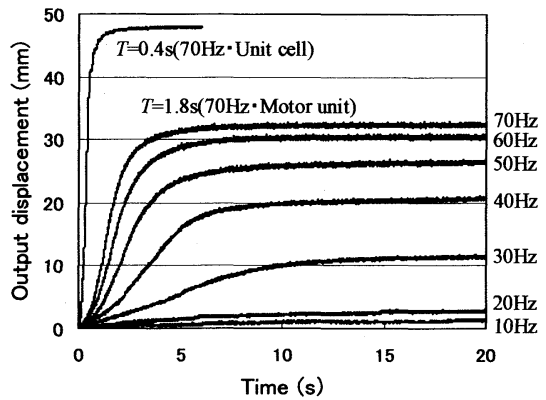

(b) Output displacement

Fig. 6 Pulse frequency dependency on step response of motor unit and unit cell
うことを目的として，入力パルスの幅を図 7 のように 段階的に変えて適正な投入電力を実験的に検討した。 図 8(a)，(b)にパルス幅をパラメータにしたパルス 周波数 $70 \mathrm{~Hz}$ における発生力と発生変位のステップ 応答を示す. パルス幅は, 運動単位では $0.5,1.0,2.0$ $\mathrm{ms}$ で, 単セルでは $0.5 \mathrm{~ms}$ である. なお，運動単位の 場合の冷却液流量は図 6 の場合と同様に $105 \mathrm{ml} / \mathrm{min}$, 単セルのそれは $14 \mathrm{ml} / \mathrm{min}$ である.

この図 8 において, 運動単位の発生力のステップ応 答の時定数 $T$ はパルス幅 $0.5 \mathrm{~ms}$ のとき $1.5 \mathrm{~s}$ であり， 単セルの場合の $0.6 \mathrm{~s} よ 0.9 \mathrm{~s}$ も長いが, パルス幅

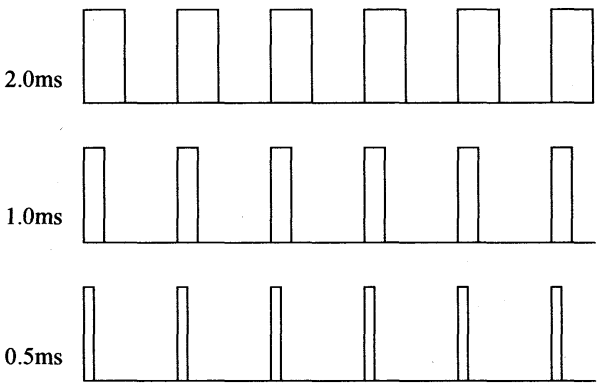

Fig. 7 Pulse width pattern

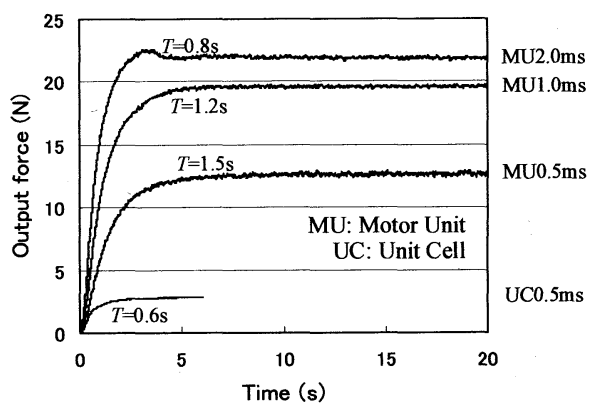

(a) Output force

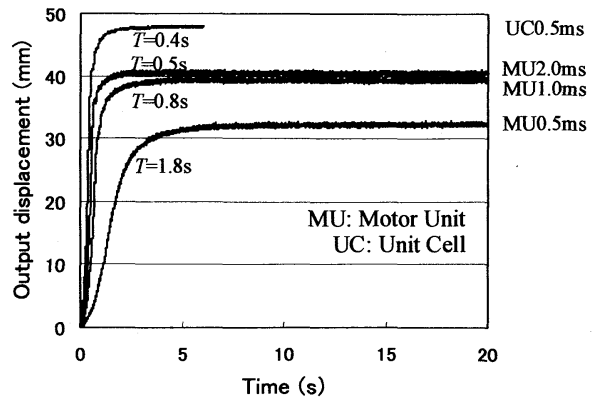

(b) Output displacement

Fig. 8 Pulse width dependency on step response of motor unit and unit cell 
を $2.0 \mathrm{~ms}$ に拡大すると $0.8 \mathrm{~s}$ となる。同様に発生変 位のステップ応答の時定数もパルス幅 $0.5 \mathrm{~ms}$ のとき $1.8 \mathrm{~s}$ で, 単セルの場合の $0.4 \mathrm{~s} よ り 1.4 \mathrm{~s}$ 長いが, パルス幅を $2.0 \mathrm{~ms}$ に拡大すると $0.5 \mathrm{~s}$ となるこの ようにパルス幅を拡大すれば，単セルのレベルにまで 時定数を短縮できることがわかった。

$4 \cdot 4$ パルス周波数と時定数 図 $9(\mathrm{a}),(\mathrm{b})$ にパ ルス幅をパラメータにして, 発生力と発生変位におけ るパルス周波数に対する時定数の関係を示す．図 9 か ら,パルス幅 $1.0 \mathrm{~ms}$ 以上, 周波数 $40 \mathrm{~Hz}$ 以上では, 時 定数が周波数の影響をあまり受けずにほぼ一定值に収 束し，パルス幅を制御することで, 周波数の時定数に 及ぼす影響を小さくできることがわかった。周知のよ うに，時定数が入力レベルに影響を受ける制御系は， 一般に設計しづらい。本研究において用いられている PFM 制御では，周波数がその入力レベルに該当する。 したがって, これは本研究における人工筋肉の制御系 を設計するうえで大変重要な結果と考えられる。

$4 \cdot 5$ パルス周波数とパワー変換効率 図 10 にパ ルス幅をパラメータにして, パルス周波数に対する当 該アクチュエータのパワー変換効率を示す。パワー変 換効率 $\eta[\%]$ は, 次式で求められる.

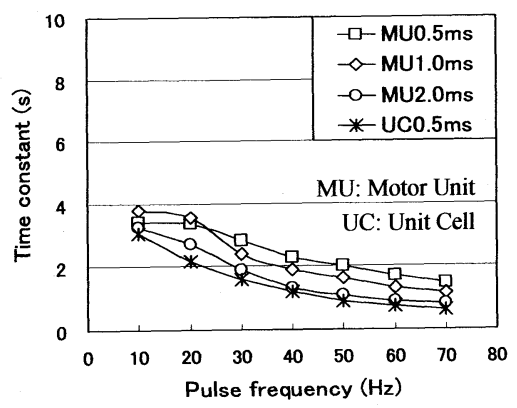

(a) Output force

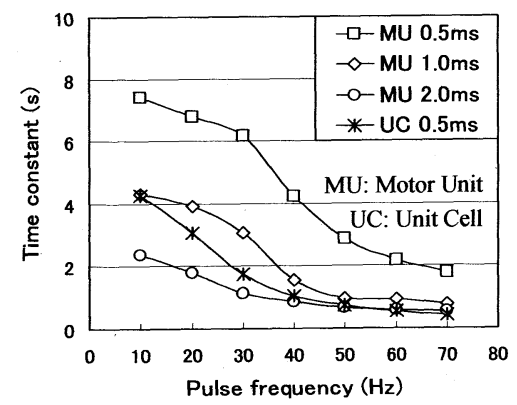

(b) Output displacement

Fig. 9 Pulse frequency dependency on time constant of motor unit and unit cell

$$
\eta=\frac{m g \cdot(0.63 L / T)}{P} \times 100
$$

ここで,

$\eta:$ パワ一変換効率 \%

$m$ : 分銅の質量 $\mathrm{kg}$

$g:$ 重力加速度 $\left(9.8 \mathrm{~m} / \mathrm{s}^{2}\right)$

$L:$ 発生変位の定常値 $\mathrm{m}$

$T$ : 時定数 $\mathrm{S}$

$P:$ 投入電力 $\mathrm{W}$

この式で, $0.63 L / T$ は単セルまたは運動単位の平均 速度 $[\mathrm{m} / \mathrm{s}]$ であり,これに分銅荷重 $m g[\mathrm{~N}]$ を掛けて 仕事率 $[\mathrm{W}]$ を求め, 投入電力 $P[\mathrm{~W}]$ で割った值をパ

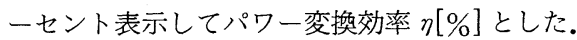

図 10 について, 単セルのパワー変換効率はパルス 周波数 $30 \mathrm{~Hz}$ 以上において約 $9 \%$ で, 従来, 形状記憶 合金のパワー変換効率は 10\%程度とされており ${ }^{(7)}$, ほ ほこの値が達成されている。これに対し，運動単位の パワー変換効率は周波数 $20 \mathrm{~Hz}$ 以上において数\%程 度であった。パルス幅を拡大するとさらに低下するこ とから,パルス幅を単純に拡大しただけでは省エネル ギーの面から問題が発生する可能性がある。

以上の結果から, 運動単位はパルス幅を拡大すると 時定数が周波数の影響を受けにくくなる高周波域で, パワー変換効率が低下する傾向が認められた。

$4 \cdot 6$ 生体筋と運動単位の比較 表 3 に生体筋と 運動単位のデー夕を比較したものを示す．表 3 を作成 するに当たり，今回製作の運動単位と比較するための モデル生体筋のデータは，寸法が運動単位と同じ外径 $\phi 4.5 \mathrm{~mm}$, 長さ $100 \mathrm{~mm}$ で体積 $1590 \mathrm{~mm}^{3}$ の生体筋 を想定し, 文献 $(4) \sim(6)$ を参考に換算して求めた.

以下, 表 3 の内容について述べる。まず, 重量につ いて, 運動単位は $1.05 \mathrm{~g}$ でモデル生体筋 $1.63 \mathrm{~g}$ の約 64\%である. 密度について, 運動単位は $660 \mathrm{~kg} / \mathrm{m}^{3} て ゙$ モデル生体筋 $1020 \mathrm{~kg} / \mathrm{m}^{3}$ の約 $65 \%$ である。力電

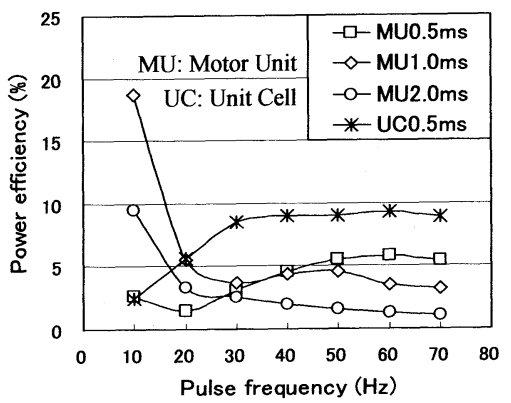

Fig. 10 Pulse frequency dependency on power efficiency of motor unit and unit cell 
Table 3 Compared natural muscle with motor unit

\begin{tabular}{|l|c|c|}
\hline \multicolumn{1}{|c|}{ Item } & $\begin{array}{c}\text { Natural } \\
\text { muscle }\end{array}$ & $\begin{array}{c}\text { Motor } \\
\text { unit }\end{array}$ \\
\hline Diameter $(\mathrm{mm})$ & \multicolumn{2}{|c|}{$\phi 4.5$} \\
\hline Length $(\mathrm{mm})$ & \multicolumn{2}{|c|}{100} \\
\hline Volume $\left(\mathrm{mm}^{3}\right)$ & \multicolumn{2}{|c|}{1590} \\
\hline Blood temperature $\left({ }^{\circ} \mathrm{C}\right)$ & \multicolumn{2}{|c|}{36} \\
\hline Impulse width $(\mathrm{ms})$ & 0.5 & 2.0 \\
\hline Weight $(\mathrm{g})$ & 1.63 & 1.05 \\
\hline Density $\left(\mathrm{kg} / \mathrm{m}^{3}\right)$ & 1020 & 660 \\
\hline Maximum output force $(\mathrm{N})$ & 7.95 & 21.9 \\
\hline Maximum output displacement $(\%)$ & 50.0 & 40.5 \\
\hline Minimum time constant of output force $(\mathrm{ms})$ & 40 & 800 \\
\hline Maximum output pressure $(\mathrm{MPa})$ & 0.50 & 1.38 \\
\hline Maximum output force / weight & 497 & 2127 \\
\hline Maximum output pressure / density $\left(\mathrm{kPa} \cdot \mathrm{m}^{3} / \mathrm{kg}\right)$ & 0.49 & 2.09 \\
\hline
\end{tabular}

圧のパルス幅が $2.0 \mathrm{~ms}$ の場合, 最大発生力について, 運動単位は $21.9 \mathrm{~N}$ でモデル生体筋 $7.95 \mathrm{~N}$ と比べて 約 3 倍である. 最大発生変位について, 運動単位が元 の長さの $40.5 \%$ でモデル生体筋 $50.0 \%$ の約 8 割であ る. 発生力の最小時定数について, 運動単位は 800 ms [図 9(a)参照] でモデル生体筋 $40 \mathrm{~ms}$ の約 20 倍 である.最大発生圧力について, 運動単位は 1.38 $\mathrm{MPa}$ でモデル生体筋 $0.5 \mathrm{MPa}$ と比べて約 3 倍であ る. 最大発生力/自重比は, 運動単位の場合 2127 でモ デル生体筋の 497 と比べて約 4.3 倍である. 最大発生 圧力/密度比について, 運動単位は $2.09 \mathrm{kPa} \cdot \mathrm{m}^{3} / \mathrm{kg}$ でモデル生体筋 $0.49 \mathrm{kPa} \cdot \mathrm{m}^{3} / \mathrm{kg}$ と比べて約 4.3 倍 である.ちなみに, 電磁気アクチュエータは 0.1 $\mathrm{kPa} \cdot \mathrm{m}^{3} / \mathrm{kg}$ 以下である(8).

以上より, 本研究の運動単位の特性は生体筋と比べ て, 重量, 密度が約 $65 \%$, 最大発生力, 圧力が約 3 倍, 最大発生変位が約 8 割, 最大発生力/自重比, 発生圧 力/密度比が約 4.3 倍, と生体筋に比べて非常に良好 であると考えられる。一方，応答性で見ると運動単位 は生体筋の約 20 倍の時定数を有しているが, 今回の 実験結果からパルス幅を制御することで時定数をある 程度改善できることがわかった。

\section{5. 結言}

高い電気絶縁性と耐熱性と柔軟性をもつ巻フィルム チューブを提案し，それにSMAコイルばねを挿入し， そこに不活性液体を通して冷却するアクチュエータを 組立て基本単位の単セルとし, 生体神経インパルスと 同じ幅のパルスによる PFM 駆動実験を行い, 人体同
様の制御ができる可能性を見出した(1).

本報では，この単セルを束ね合わせて運動単位を組 立て, 単セルの場合と同様に, 生体神経インパルスと 同じ幅のパルスによる PFM 駆動実験を行い,さらに パルス幅の変化による応答性能を評価した。その結果 は以下のとおりである。

（1）生体と同じ帯域におけるパルス周波数に対す る発生力と発生変位の静特性は単セル 1 本の場合に比 べて，よりいっそう比例関係に近づく.

（2）同一周波数条件において，パルス幅の変化で も入熱量を制御できる.

（3） パルス幅を拡大すると時定数が周波数の影響 を受けにくくなる高周波域ではパワ一変換効率が低下 する傾向が認められた。

この結果, 単セルを束ね合わせて運動単位にすると, 生体神経インパルスによる直接駆動の可能性が，より 高くなるが, 同時に時定数が延長化する問題が生じ, この改善のためパルス幅を拡大すると, 制御しやすい 高周波域でパワー変換効率が低下する傾向が認められ た. 今後は, パワー変換効率を落とさずに時定数を改 善する制御システムを検討していく予定である.

\section{文献}

(1) Ishikawa, T. and Nakada, T., Shape Memory Alloy Actuator for Artificial Muscle (Proposition of Rolled Film Tube Method), Transactions of the Japan Society of Mechanical Engineers, Series C, Vol.71, No.703 (2005), pp. 944-950.

(2) Ishikawa, T. and Nakada, T., Study on Artificial Muscle Actuator using Shape Memory Alloy (2nd Report, Characteristics of Motor Unit), Proceedings of the 41st JSME Tohoku Branch Autumn Conference, (2005-9), pp. 71-72.

(3) Ishikawa, T. and Nakada, T., Study on Artificial Muscle Actuator using Shape Memory Alloy (3rd Report, Improvement of Motor Unit's response time), Proceedings of Fluid Power System Conference 2006 Autumn, (2006-11), pp. 58-60.

(4) Wirhed, R., Athletic Ability \& the Anatomy of Motion, (1996), p. 13, Taishukan Publishing Company.

(5) Yamamoto, K. and Maruyama, K., Muscle (in Japanese), (1986), p. 14, Kagaku-Dojin Publishing Company. INC.

(6) Miyamura, S. and Yabe, K., Physical Workouts (in Japanese), (1986), p. 19, Shinko Trading Co. Ltd. Publication Department.

(7) Hunter, I. et al., Fast Reversible NiTi Fibers for Use in MicroRobotics, Proceedings of the 1991 IEEE Micro Electro Mechanical Systems-MEMS'91 Nara Japan, (1991), pp. 166-170.

(8) Ashley, S., Artificial Muscles, SCIENTIFIC AMERICAN , (2003-10), pp. 34-41. 